\title{
Terrorism in Central Asia: Security Implications for Russia
}

\author{
Debendra Mahalik
}

Abstract

\begin{abstract}
End of the cold war following the disintegration of the Soviet Union witnessed unprecedented increase in militancy and terrorism prompted by internal and external forces. This was also fuelled by factors like religious fundamentalism and ethno-nationalist chauvinism. The newly independent countries of the Central Asian region encountered myriad problems like terrorism, drug trafficking, arms trafficking, organized crime, separatism, and ethnic conflicts. Given the geographical proximity and historicity, Central Asia is regarded as Russia's own backyard and a "soft underbelly". The near-abroad security developments in the Central Asian republics have great influence on Russia and could create a complex environment detrimental to its security interests. The Russian approach to this challenge is of great importance for the stability of the whole area. Any negative developments in Central Asian Regions and Afghanistan would have serious security implications for Russia. A stable and friendly government in Afghanistan and Central Asian states would prove beneficial to Russian security, including the on ongoing separatist movements in Chechnya and Dagestan. Therefore it is imperative that Russia and Central Asian states act collectively to counter religious radicalism and foster regional stability. This article examines some factors responsible for breeding terrorism and religious extremism in Central Asian Republics and its security implications onRussia such as Central Asian threats, US presence in Central Asia and the Taliban in Afghanistan.
\end{abstract}

Keywords:Terrorism, religious extremism, security, Central Asia, Russia, Afghanistan, Chechnya.

\section{Introduction}

Terrorism has gained prominence as among the non-traditional threats in the world. Combating this threat is a major issue confronting most of the governments in the world today. It has assumed a new dimension with the formation of international ideological, financial and technological networks. These linkages have made terrorism a potent source of destabilization, both regionally and internationally. The September 11, 2001 attack on World Trade Center and Pentagon in the United States of America has unveiled the bad face of this new menace. Though this threat is evident everywhere, in some form or other, it is more serious in countries like Russia and the Central Asian Republic (CARs).

After the implosion of the Soviet Union, Russia emerged as a major player in the Central Asian geo-political order. However religious extremism and terrorism in Central Asia has not only 


\section{Debendra Mahalik}

threatened the geo-strategic interests of Russia but also created a complex environment in security interest. Russia has been facing challenges from religious extremism and terrorism in Chechnya and Dagestan emanating from Central Asia, Afghanistan and Pakistan. Russia considers Central Asia to be an important region with vital geo-strategic, security and economic interests and is keen in maintaining peace and stability in this region. Any negative developments in Central Asian regions and Afghanistan would therefore have serious security implications for Russia. So, a stable and friendly government in Afghanistan and Central Asian states free from religious radicalism and terrorism is what Russia favours.

\section{Brief Background}

In the beginning of the last century, Sir Hartford Mackinder, a geo-political theorist postulated his 'Heartland Theory' that dwelt upon the geopolitical importance of the Eurasian heartland, bounded by the Volga and Yangtse Rivers and the Himalayas in the south and the Arctic Ocean in the north. His theory has never been fully tested however it highlighted the strategic significance of the Central Asian region. Central Asia is fortunate to be situated in one of the most geostrategic locations of the world, in the core of Eurasia that seminally Zbigniew Brzezinski once coined "the center of world power" (Zbigniew, 1998, p. 13). Without doubt, its position between Russia, China, and Iran, and being at the crossroads of the trade and energy routes, along with the region's vast energy resources are adequate evidence of its importance. Today, the region consists of the former Soviet Republics of Kazakhstan, Kyrgyzstan, Tajikistan, Turkmenistan, and Uzbekistan, which all declared their independence from the Soviet Union in 1991. The five republics share not only a common social and cultural heritage, but also a number of security threats such as religious radicalism, crime, corruption, ethnic and civil conflict, water disputes, border tensions, and drug trafficking. Nevertheless according to a number of authors "the revival and radicalization of Islam" has been the most notable development and major threat for the post-soviet Central Asia (McGlinchey, 2005, p. 336). Indeed, the series of terrorist attacks that Kazakhstan experienced in the last months of 2011, most of them committed by a previously unknown Islamic terrorist organization - Jund- al-Khilafa (Soldiers of the Caliphate), have once again highlighted the enduring and critical problem of Islamic extremism that the whole region of Central Asia has been facing since the demise of the USSR. In fact, the latest and most appalling incident, the suicide bombing in Taraz on the 12th of November 2011, that killed no less than 30 people has stunned the country, (Lillies, 2011). Indeed, "while jihadist terrorism has been a part of the Central Asian political landscape for a long time, these events deserve special attention," as this surprising number of attacks were inflicted on the most stable and secular state of the region namely Kazakhstan.

\section{Central Asian Terror Conundrum}

Radical Islamic opposition movements have a long history in Central Asia dating back to the Tsarist era. Though these states are bastions of moderate and traditional Islam and among the most secularized areas of the Muslim world, radicalism has made a forceful comeback in 
the past three decades. During World War I, for example, Islamic militants took up arms to oppose the Russian government's attempts to mobilize Muslims to work in the front. Again, in the 1920s, Muslim partisans in the so-called Basmachi movement opposed the Bolshevik takeover and the advance of soviet power into Central Asia (Hill, 2003, p. 2). And, the most recent resurgence of Islamic opposition was spurred by the 1979 Soviet invasion of Afghanistan. This tied Central Asia's and Afghanistan's fates together in many respects. Central Asian Muslims sent to fight in Afghanistan gained new appreciation for their history and religion and drew inspiration from the mujahidin fighters who opposed the invasion. By the late 1980s, alien Islamic proselytizing had gathered speed across the Muslim regions of the former Soviet Union, and had resulted in the spread of radical ideologies, militancy, and terrorism. Worst hit has been the Russian North Caucasus and some parts of Central Asia, especially the Ferghana valley shared by Uzbekistan, Kyrgyzstan and Tajikistan. Radical Islamists have long been interested in Central Asia, a historic centre of classical Islam located in a region of strategic importance. Yet, they entered the region in significant numbers only since the late 1980 s, as it had been closed off to the rest of the Islamic world by decades of harsh Soviet rule (Baran, 2006, p. 7). After the 1989 Soviet withdrawal from Afghanistan and the subsequent collapse of the USSR, international Muslim brigades were establishedto provide manpower for Islamist insurgents to operate in Central Asia.

The central spot of the Islamic radicalization and extremism has been identified with the Ferghana Valley region, a densely populated and ethnically Uzbek territory divided politically between Uzbekistan, Kyrgyzstan, and Tajikistan, where the "Islamic sentiment has already expressed itself since the early 1990's" (Cornell, 2002, p. 199). In fact, Uzbekistan and Tajikistan have since then been recognized as the most conflict-prone countries of the region as the former gave birth to one of the most dangerous terrorist organizations Islamic Movement of Uzbekistan (IMU), and the latter experienced a vicious five year civil war, also known as Tajiki Civil War between 1992-1997. Uzbekistan is therefore the birth place of the notorious IMU, along with its splinter groups the Islamic Jihad Union (IJU) and the Islamic Movement of Turkestan (IMT). The formerwhich is considered responsible for numerous terrorist attacks in Central Asia (Cordesman, 2011 Online Web) has forged links with al-Qaida and has operated in Afghanistan and Pakistan against the NATO forces (Nichol, 2010). Though its first step was mainly against Karimov's regime in Uzbekistan, the IMU has declared as its main objective to "overthrow the secular governments of Central Asia and to establish an Islamic Caliphate" (Buszynski, 2005, p. 547). Although the group has been inactive in Uzbekistan since 2001, it continues to operate out of the country's borders.In fact members of the IJU have been arrested even in Germany in 2007-8 (Chaudet, 2008, p. 19). Another radical group that has found fertile ground in Central Asia and has shared the goal of the creation of a caliphate in the region is Hizbut-Tahrir alIslami (Party of Liberation - HT). However, HT is first of all a political organization with international activity that initially appeared in Central Asia in the middle of the 1990s. Moreover, although the emergence of the group in the area was initially considered a "Uzbek phenomenon" (Karagiannis, 2010), it has also thousands ofmembers and supporters in each of the five republics, despite the fact that it "uses propaganda to disseminate its stated goal 


\section{Debendra Mahalik}

of non-violent means of overthrowing of Western governments," (Amanbayeva, 2009, p. 173). Tajikistan also has deeply suffered from extremist violence, since its independence it became not only the terrain of a murderous civil war (1992-1997) between the Communists and the Islamists (McGlinchey, 2005, p. 338), but has also unintentionally offered refuge to the IMU, which joined the war on the side of the Islamists and has since then used the country as "a conduit for its operations" (Menon, 2003, p. 190) in Uzbekistan, Kyrgyzstan, and the greater area. Indeed, with the exception of Turkmenistan, the other states of Central Asia, namely Uzbekistan, Tajikistan, and Kyrgyzstan have already been confronting regional threat in the face of IMU and its splinter groups, according to Didier Chaudet, an "“Al-Qaedian' threat," (Chaudet, 2008, p. 4).

\section{Causes Behind Terrorism and Religious Extremism in Central Asia}

Since their independence Central Asians Republics have become an area of economic failure, political repression and growing source of Islamic extremism. While the region continues to be the most promising in terms of its energy resourcesand its geo-strategic location, radical Islam remains a cause of great concern for these republics. Therefore any attempt at understanding and examining the problem of religious extremism in Central Asian Republics would be futile without mentioning the root causes of the problem. According to Meena Singh Roy, a Central Asian expert, five major causes can be attributed to this rising religious extremism and terrorism in Central Asian states (Roy, 2004: 186-187), i.e. breakup of Soviet Union and creation of ideological vacuum, rise of Taliban in Afghanistan, hard-line and repressive policies of Central Asian regimes, unemployment and poor living conditions and lack of democratic and economic reforms.

\section{Break-up of Soviet Union}

The breakup of Soviet Union created an ideological vacuum in this region. After independence, Islamic revival swept through this whole region. Under soviet system all forms of religious expression were repressed in these states. Therefore when the soviet empire fell apart, the people of Central Asia who had been forced to renounce or hide their religion for 74 years, saw at last the opportunity to connect themselvesspiritually and culturally with the Islamic past. However, in recent years Islam as a religious tradition and as a form of 'cultural and political identity' has acquired new meaning in Central Asian republics (Laqueur, 2003, pp. 190-91). After independence, a whole lot of Islamic missionaries from Saudi Arabia, Iran, Pakistan, Turkey and many other countries had been pouring into Central Asian Republics. However the religious fervor of Central Asian Republics wasnot handled carefully by the rulers of this region. Instead the highly centralized, post-soviet ruling elites adopted repressive measures which created internal unrest situation where religious extremist operating in the neighboring states could easily cultivate support for their cause (Rashid, 2002b, pp. 5-6). 


\section{Rise of Taliban in Afghanistan}

Afghanistan has always been crucial to the security of Central Asian states. The rise of Taliban in Afghanistan set in place a model of extremist Islamic fundamentalism unknown in this part of this Muslim world. With the help of Saudi extremist Osama bin Laden, Taliban ruledAfghanistan (1996-2001) became a base for exporting Islamic militancy to neighboring countries. It became a centre for training the terrorist and spreading instability in the region (Rashid, 1999, p. 7; Roy, 2004, pp. 186-189).

\section{Hard line policies of Central Asian Regimes}

Shortsighted hard line policies of the Central Asian regimes (Kazhakstan, Kyrgyzstan, Uzbekistan, Turkmenistan and Tajikistan) have also helped the militants cause. As far as internal situation in these republics is concerned, we find that there is growing dissatisfaction among the elites as well as other section of society against the ruling regimes of CARs. There is repressionof oppositionparties, Islamic groups and the media by Central Asian elites. Mohammad Solih, leader of Uzbekistan's banned freedom party, who has been in exile in Norway since 1992, wrote in the New York times on March 11, 2002 that "twelve years have passed but the democratic human rights abuseby one party state has not changed and neither has western support for them." He further stated, "Karimov shows it is possible to gain prestige and money and extend your role on a whim and still gain American support in the post terrorism world" (Rashid, 2002:8). According to Boris Shikhmuradov, the former foreign minister of Turkmenistan, "there has been stagnation in Central Asia for ten years and now all the presidents are trying to extend their political life (Rashid, 2002a, p. 210).

\section{Poverty and Unemployment}

Poverty and unemployment is on the rise in most of these states especially in the Ferghana valley, the hub of extremism, is another reason for terrorism and religious extremism. According to World Development Report and World Bank (2009), up to $46.7 \%$ of the population lives below poverty line in Tajikistan, $31.7 \%$ in Kyrgyzstan and 26\% in Uzbekistan (World Development Report, 2012). Well known Uzbek political scientist, BahudirMusayev, is of the opinion that declining living standard in Uzbekistan has given fresh strength to the IMU detachments from the Ferghana valley. Brutal repression by the ruling elites has alienatedthe unemployed who are already dislodged by the lack of economic opportunity and disillusioned with the persistent institutional failure of the government to provide even the barest semblance of a just and efficient state. Consequently, Islamic militant network easily recruit more fighters from these ranks (Makerenko, JanesIntelligence Review, 2002, pp. 30-33).

\section{Lack of Democratic Reforms}

The progress made by all five republics on the path to economic and political reforms has slowed down. Many critical economic reforms are stillborn or incomplete, and state 


\section{Debendra Mahalik}

controlled and corruption remains pervasive. In this context Ahmed Rashid has stated in his book "Taliban Militant, Oil, and Fundamentalism in Central Asia" that America, Russia and China regard the dictatorial regimes of Central Asia as allies against an Islamic fundamentalist threat. However not one of them is working for the kind of democratization and development that would undercut the appeal of Islamic revolutionary movements in the region. He has very forcefully argued that repercussion and poverty are the root causes of this problem. So long as poverty and unemployment increases and economic opportunities decreases, the Central Asian states provide fertile ground for any radical organization to operate. Therefore, any attempt to militarily defeat these Islamic revolutionary movements, will not eliminate the true causes. Only development and democratization can help in combating this menace of religious extremism in CAR's (Rashid, 2002, p. 228).

\section{Ethnic dimension and Religious extremism}

Some ethnic analysts have examined systematically the ethnic dimension of religious extremism, political violence, and terrorism in the Central Asian states (Omelicheva, 2010, p. 167; Omelicheva, 2007). These studies have demonstrated that ethnic minorities residing in the territories of the Central Asian republics, particularly, Uzbeks in Tajikistan, Kyrgyzstan, Kazakhstan, and Turkmenistan, and Tajiks in Uzbekistan, have been attracted to radical Islamic groups and have become involved in the acts of political violence and terrorism. Islamic radicalism has become an expression of ethnic identity, particularly for Uzbeks leaving in the Kyrgyz and Tajik parts of the Ferghana valley. The growing authoritarianism of the Central Asian governments, assaults on religious freedoms, and social and informal constraints on cultural and political rights of the Uzbek and Tajik ethnic minorities have contributed to the greater popularization of radical Islamic organizations among these ethnic groups. (Omelicheva, 2007). Though Central Asian terrorism is much influenced by drug trafficking, small arms trading and ethnic dimensions, and its patronage by states across borders has become more potent in the post-independent period.After the Soviet withdrawal from Afghanistan, the emergence of Taliban with patronage from Pakistan, and its spread to Central Asian states, particularly to Tajikistan and Uzbekistan, has created a dangerous platform to convert Central Asia into a hotbed of terrorism and Islamic extremism. (Mahapatra, 2008). One would like to underscore the fact that although there is certainly a link between terrorism and religious extremism in Central Asia, much of the extremism that we see is fueled by the radicalization of politics in the region rather than by political Islam, as governments have steadily narrowed the space for legitimate political opposition and broad-based public participation in politics.

\section{Security Implications for Russia}

Any attempt to understand Russia's evolving role in Central Asia would be futile without identifying the major security threats that it is facing today. As a Great Power or a former Great Power aspiring to regain its lost status, Russia cannot merely consider security 
problems arising from within its borders, but from neighbouring countries as well. There are two areas where potential religious extremism and terrorist threat could have an impact on Russian security. First is the threatfrom post-soviet Central Asian states. Second,is the US presence in Central Asia and thirdly there is a threat fromAfghanistan, or to be more precise, the Afghan and the Pakistani Pashtun area where the Taliban and their foreign jihadist auxiliaries are based (Chaudet, 2009: 51).

\section{Central Asian Threats to Russian Security}

Stability in Central Asia is indeed crucial for Russian security and its domestic politics. There are a number of reasonswhy a stable Central Asia is in the interest of Russia. Among of the important factors are resurgence of Taliban and problem of Islamic extremism emerging out of Afghanistan; drug trafficking and smuggling of arms; and weapons proliferation (The Hindu, 2 Feb 2006). The traditional political and military dimension of security has largely lost its dominant role in the contemporary Russian perception of security. The National Security concept, drafted by the Security Council of the Russian federation and approved by a presidential decree on December 17, 1997, indicates for instance, that "the analysis of threat to the national security of the Russian Federation reveals that most of those threats are currently and in the foreseeable future is of a non military nature (Horsman, 2005, p. 209). These include the threats posed by drug trafficking, terrorism, organized crime, degradation of the environment, challenges of mass migration and Islamic radicalism. An analysis of Russia's threat perceptionin relation to Central Asia's position in these reveals that the Central Asian Republics are at the center stage in these perceptions (Roy, 2001, pp. 456-60). These new states, with their inherent regime weaknesses are faced with mixed problems like ethnic and religious disputes, drug trafficking arms smuggling and Islamic extremism. Moreover, the fight among the various countries for greater control over the enormous energy resources of Central Asia threatens Russia's geo-strategic role in this region.Despite this, under no circumstances would Russia allow its position to diminish in this region. To safeguard its security interests in the Central Asian Republics, Moscow is making every possible effort to maintain a pivotal role in the region.

The ethno-nationalist conflict in Tajikistan in May, 1992 proved instrumental in giving an assertive turn in pushing the Russian policy towards the Central Asian states. As a result, after an initial phase of indifferent policy, Russia made concerted efforts to restore its economic domination as well as military grip over Central Asia with a view of deterring all external and regional powers from filling the geo-political gap and strategic access in the region. Undoubtedly, 'soft security' (Alam, 2008, p. 174) concerns have already attracted Russia to get entrenched in the Central Asian affairs. But Russia needs a forward based approach particularly towards any possible infiltrations of Islamic radical forces from its southern region which are bent on civil war in Chechnya and other Russian republics. The spread of radical Islam from Afghanistan into the bordering Central Asian countries of Uzbekistan, Tajikistan, and Turkmenistan - often referred to as Russia's "soft underbelly"is something Moscow fears, especially if its war against Islamists insurgents in Chechnya 
continues (Withington, 2002, p. 42). So Russia's military presence in the Central Asian states of Uzbekistan and Kyrgyzstan will not only help keep an eye on the states of Afghanistan, Pakistan, Iran and other countries, but also respond to threats when the need arises.

Apart from this Russia will also be able to become an important power broker in the regions politics by having the ability to mediate local conflicts that often develop along ethnic lines. Simultaneously, it can exploit Russian diasporas to prevent regional ethno-national unrest. The success in the Afghanistan war may also help put down Russian concerns about the Taliban gaining a foothold in Central Asia. The Central Asia states are home to many ethnic Russian and also contain significant Russian military facilities. Russia fears that any coup by radical Islamist elements within its Southern neighbors'that might install regimes sympathetic to the Taliban may resultin influx ofabout 10 million ethnic Russian refugees arriving at the doorstep of the mother Russia. Destabilization of any state in this region would mean, at the very least, a larger flow of Muslim emigrants from Central Asia to Russia. Additional Central Asian immigrants could trigger the Russian extreme right further, stir anti-Muslim sentiment in the population, and reinforce links with criminal groups operating in the country in question. It is exactly for these reasons that Moscow decided to intervene in the Tajik civil war (Johnson, 2006, p. 44). It was this possibility along with the Chechen concerns that led Russia to hedge its bets and support a united front government in Afghanistan and anti terrorism coalition force led by USA.

\section{US Presence in Central Asia}

Another security implication to Russia is the increasing presence of US forces in the Central Asian region. America's war on international terrorism resulted in a US led NATO military presence in the Central Asian region posing direct challenge to Russia's security interest. In Central Asia, the USA increased its influence, especially after 2001 anti-Taliban war. Its economic and strategic interest found synergy after the 11 September bombings. American troops were stationed in a region that is on the border of two potential global adversaries Russia and China (Buszyniski, 2005:546). Troops are also embedded in a region near the Caspian states where its energy interests and investments could be backed up by force if necessary. By becoming the major economic and security player in the region, Russia does not expectto be marginalized by the United States or any other potential competitor in the region. After the humiliation of the 1990s and Russia's marginalization as a great power supported by the West in general and by the U.S. in particular - it is quite rational that the presence of another great power, in an area it considers as its zone of influence, irks Russia. It is even more so considering the persistency with which the U.S. has sought to strengthen the Central Asian states independence, something that has been seen by Russia as a way to limit Moscow's political influence (Wishnik, 2002, p. 5). The Russian point of view has been clearly expressed by VyacheslavAlekseevichNikonov, director of the influential Russian think tank PolityFoundation (Online Web): "We [Russia] and the Western countries have diametrically opposite definitions of success in our policy toward the CIS [Commonwealth of Independent States] countries. For Russia, success lies in strengthening of integration 
ties, rapprochement with its neighbours and a strengthening of cooperation. For the West, on the contrary, success means distancing these countries from Russia, a reorientation to external centres of power aimed at preventing 'a rebirth of the Russian empire'. When political goals are so diametrically opposed, it is impossible to speak of a common agenda." (Bhadrakumar, 2008, p. 10). Since, from the Russian point of view, there is no overlapping "common agenda", it is logical to see the Kremlin as systematically trying to limit U.S. influence in Central Asia, in particular its symbol, the American military bases. It can be seen as part of the "Putinian Reaction" and Russia's attempt to reclaim its great power status. In July 2005, it became clear that Russia was one of the architects of the termination of all American operations in Uzbekistan, and the subsequent evacuation from the famous Karshi-Khanabad (K2) air-base (BBC News, 2005). In the same way, it is no surprise that the Kyrgyz president, KurmanbekBakyev, announced in Moscow on February 3, 2009, that the air-base on Kyrgyz soil, in Manas, had outlasted its original goals linked to the War on Terror. Indeed, in the same period, Russia and the other Collective Security Treaty Organisation (CSTO) members agreed to create a rapid-reaction military force that should be able to answer regional security threat and terrorism.

During the Yelstin era Central Asia lapsed into the backburner, but Putin revived Russia's interest to strengthen its role in the region because of Islamic radicalism, fear of displacement by Americans and the presence of oil and natural gas reserves. Since Putin's accession to leadership in Russia, the country's foreign policy has shifted to give it a stronger "near abroad" (Roy, 2001, p. 457) orientation. Later, the Chechnya conflict, which brought Vladimir Putin to power, also forced Russian government to adopt a more active and determined policy of reversing the trend and strengthening Russian influence in Central Asia. This facilitated Russia's increased military and economic presence in Central Asia following the stationing of American troops in the region in 2001. Russia's expansion of its presence was made possible due to the earlier steps taken by Russia to remain engaged with the region right since the Tajik Civil War beginning in 1992. The signing of the Collective Security Treaty (CST) that year resulted in massive troop deployment along the Tajik-Afghan border and guaranteeing the security of Tajikistan from external aggression. As for the Russian 201st Motorized Rifle Division, which has been stationed on Tajik territory since the Soviet period, it supported the anti-Islamists faction from the very beginning (Johnson, 2006, p. 45). Such an approach is rational in the short term: the goal is to obtain stability, regardless of costs. The Tajik Islamists were close to the Afghan mujahidin, something that could only bode ill for Moscow. Russia's role in Central Asian security further expanded to support the Northern Alliance during Taliban days in power in Kabul. Uzbekistan, which had left the treaty of Collective Security, signed bilateral agreements on military and militarytechnical cooperation, described as Russian-Uzbek relations as "strategic partnership" (The Hindu, 2006, p. 10). Later, the chain of events in Dagestan, Chechnya, Uzbekistan and Kyrgyzstan increased the common fear of Islamic extremism and provided president Putin with a platform to suggest closer cooperation in the military and security fields which also supplanted to reorient the Central Asian states back towards Russia. As such Russia wants 


\section{Debendra Mahalik}

a strong presence in its former territories is to deter the US from gaining any footing in the region.

\section{Afghanistan Terror and Russian Security}

Terrorists in Afghanistan pose another security problem to Russia. As a turbulent neighbour threatening the stability of the Central Asian states in the last two or three decades and as the safe haven of international terrorists, Afghanistan is of great concern for Russian security. Of security concern for Russia is the fact that Taliban-ruled Afghanistan has accommodated many insurgent groups operating in Central and South Asia, the Middle East, and beyond (Withington, 2002, p. 41). In addition to Osama bin Laden's Al Qaeda network, the Mujahideen-e-Khaq of Iran, the Xinjiang Liberation Front of China, the Islamic Movement of Uzbekistan, and the Hizb-ul-Mujahuddin operating in Jammu and Kashmir, all took advantage of Taliban hospitality and military aid. An important concern here is the Taliban regimehas recognized Chechnya as an independent state. Hence, the Taliban regime proves to be "potentially mortal danger to regional stability to all pro-Russian regimes, Russian influence and ultimately, Russia’s own borders" (Lieven, 2002, p. 252).

The war in Afghanistan marked the increasing dominance of the Pakistan supported Taliban movement over most parts of the country. This is another major source of concern to Russia as well as number of regional actors, especially India, China, Iran, Tajikistan, Uzbekistan and Kyrgyzstan. On January 16, 2001, Kabul recognized the government of the breakaway republic of Chechnya and allowed the Chechens to open an embassy in Kabul. Following this, there were reports that 200 Taliban cadres had left to fight in Chechnya, while Chechen refugees, particularly young boys and the families of leading Chechen commanders began to arrive in Kabul and Kandahar. A joint training camp was set up in Mazar-I- Sharif to train Islamic dissidents from all over Central Asia. (Public Opinion Trends, 19 January 2001, p. 3). These developments clearly endangered the Russian security. Moscow's ambassador to Dushanbe, Maxim Peshkov, told reporters in the Tajik capital "the situation in Afghanistan is the number one problem for Central Asia and Russia. (POT, Afghanistan Series, 19 January 2001). Moscow was enraged by the presence of guerilla training camps in Afghanistan and hoped that the United Front will close these facilities if they destroy the Taliban. That hope could have been realized with the front's liberation of Mazar-I-sharif, Herat, Kunduz, and Kabul, and the United states air force attacks on "terrorists training facilities" (Withington, 2002, p. 43).It is said that many of these camps which were used to train Chechen militants have also had links with al Qaeda.

Moreover, if the coalition forces are defeated in Afghanistan, Russian security itself could be at stake more directly. Indeed, there is a common misperception about terrorist groups as being only anti-American. If Bin Laden and his followers see the U.S. as their great enemy, this has not been the case for all the jihadists based in the Afghan "emirate" of the Taliban. Indeed before the 9/11 American attack, it was believed, there were at least 14 militant groups 
or organizations in Afghanistan. If one cannot reject the idea of some kind of influence of Bin Laden on some of them, at least the Uzbek IMU is the best example (Gunaratna, 2006, p. 237). It is also mistake to think that Al Qaeda had a direct control on all of them and was able to impose its vision to the other groups. Some militant groups saw the U.S. only as one of the main enemies, with Russia as an equally important enemy. For example, for al-Suri, in the 1990s, there was an aggressive alliance between Iran, Russia, the United States, and Central Asian states, against the Taliban and their jihadist allies. Some religious extremist, including some Afghan-Arabs and Middle Eastern jihadists, were much more interested in continuing the Soviet-Afghan war, this time in Central Asia and in Russia, than to wage a war against the Americans who are deemed the strongest opponent. This practical approach was theKhattab network, which was, at least in the 1990s, as important, or even more important, than the one Bin Laden was able to establish during the same period in Afghanistan (Gerges, 2007, p. 57). Others chose the path of Khattab, even without being part of his group. Some jihadists were indeed "wanderers", without any strong affiliation to one group or another in Chechnya, just present to fight the state that they thought was the main oppressor of Muslims (Collins, 2002, pp. 96-97). Some Chechen radical Islamists, like Basayev, have been trained in militant camps in Afghanistan (Bowker, 2007, p. 79), and Chechen militants are still based in the neo-Taliban strongholds, like Waziristan. If the United States fails in Afghanistan, it is clear that the international terrorists would find a safe-haven there and would not only target the US but also Russia. Indeed, due to the weakness of the Central Asian states, and the situation in the North Caucasus, it is very possible to see the jihadist reorient their actions at least partially against Russia. Lastly, in a new Afghan "emirate", Chechen militants would also be given a safe-haven. The Chechen independence had already been recognized officially by the Taliban. As the neo-Taliban are much closer to the jihadist way of thinking than the Taliban before them, it is fair to assume that a new Afghan Emirate led by the neo-Taliban will focus on the jihadist regional causes of their allies, i.e. the jihads for the Ferghana Valley and the North Caucasus, among others. Currently the Russians seem to take a greater interest in stabilizing and supporting the Karzai government. It cancelled most of the Afghan debt as a sign of support (Online Web, 2008), and relations linked to defence and weaponry are growing. (RIA Novosti, 2002) Russia even seems to appreciate the importance of perceiving security and development in this region from a "Greater Central Asian" approach, which at last takes into account the fact that fate of Central Asia and Afghanistan are linked (Li, 2006).

From the above discussions one can interpret that any attempt to find an alternative to Russian presence in the Central Asian region has had mixed results. The early phase following independence was marked by a search for solidarity and co-operation with Islamic neighbours. The competition among Islamic states and their different brands of religious ideology and the rising threat of Taliban-inspired fundamentalist movements had a negative impact on relationship with these neighbours. The level of economic and technological development of these states could also not become a pull factor. Only Turkey as a seculardemocratic state has some visible presence in the economic and cultural sphere. Although 


\section{Debendra Mahalik}

Central Asian States have relations with major Islamic powers like Iran, Saudi Arabia and Pakistan, these are not going to be alternatives to Russia or other global powers engaged with the region.

\section{Conclusion}

Given the changing contours of the strategic environment and Russia's geo-strategic and security interests in the region, her close geographical proximity and as important regional power, Russia must not only sustain its current diplomatic thrust in the region, but also reinvigorate it to a far higher level. The geo-political stability in Central Asia has not only a direct impact on Russia's economic interests in the region, but also has greater security implications on the ongoing separatist movements in Chechnya and Dagestan. Therefore, it is pertinent that Russia and the Central Asian states act collectively to maintain regional stability, which has wider ramifications over regional security developments. The task should not be left to the US alone which is physically far away from this region and is obsessed with A1 Qaeda. The exit strategy and localization process initiated by United States in Afghanistan has compelled Central Asian Republics and Russia to think about their security interests after US troops withdrawal 2014.

\section{References}

Mohammad Monir Alam. (2008). India-Russia Cooperation in Central Asia. In P.L. Dashand Andrei M. Nazarkin. Indo-Russian diplomatic relations: Sixty years of enduring legacy. New Delhi: Academic Excellence.

Amanbayeva, A. (2009). The collision of Islam and terrorism in Central Asia. Asian Criminology, 4 (2), 173.

Baran, Z., Frederick S., \& Svante E. C. (2006, July). Islamic Radicalism in Central Asia and the Caucasus: Implications for the EU, Silk Route Paper, Central Asia-Caucasus Institute \& Silk Route Studies Program- A Joint Transatlantic research and Policy Centre, Sweden.

Bhadrakumar, M. K. (2008, June 25). Russia joins the war in Afghanistan. Asia Times.

Bowker, M. (2007). Russia, America, and the Islamic world, Farnham: Ashgate, 79.

BrynjarLia, Architect of Global Jihad, 237.

Bumiller, E., \& Ellen, B. (2009, February 5). U.S. searches for alternative to Kyrgyz base. New York Times. Retrieved from www.nytimes.org 
Buszynski, L. (2005). Russia’s new role in Central Asia. Asian Survey, 45(4), 547.

Chaudet, D. (2008). Islamist terrorism in greater Central Asia: The 'AlQaedaization' of Uzbek Jihadism, Russie.Nei.Visions, 35, 19.

Chaudet, D. (2009). When the bear confronts the crescent: Russia and the Jihadist issue. China and Eurasia Forum Quarterly, 7(2), 37-58.

CIA World Fact Book Online Web. Retrieved from www.indexmundi.com/

Collins, A. (2002). My Jihad. Pocket Star Books, 96-97.

Cordesman, A. H. (2011). US State Department and Counter-Terrorism Center reporting terrorism in the Middle East and Central Asia, August 2010. Centre for Strategic \& International Studies Report, Washighton DC. Retrieved from www. csis.org/burke/reports

Cornell, S. E., \& Spector, R. A. (2002). Central Asia: More than Islamic extremists. The Washington Quarterly, 25 (1), 199.

Gerges, F. (2007). The Far Enemy. New York: Cambridge University Press, 57.

Gunaratna, R. (2002). Inside Al Qaeda. New York: Columbia University Press, 171.

Hill, F. (2003, July). Central Asia: Terrorism, religious extremism and regional stability. Brookings Institute of Research, Testimony before House Committee on International Relations, Sub-committee on Middle East and Central Asia.

Horseman, S. (2005). Themes in official discourses on terrorism in Central Asia. Third World Quarterly, 26(1), 199-213.

Karagiannis, E. (2010, April 21). Political Islam in Central Asia: The role of Hizbal-Tahrir. Eurasia Review, 21. Retrieved from http://www.eurasiareview.com/21042010political-islam-in-central-asia-the-role-of-hizb-al-tahrir/

Lacquer, W. (2003). No end to war: Terrorism in the twenty-first century. New York: Continuum International Publishing Group.

Lieven, A. (2002). The secret Policeman's Ball: The United States, Russia and the International Order After 11 September. Foreign Affairs, 78(2), 247-59. 


\section{Debendra Mahalik}

Li,V. F. (January, 2006), “Geopolitičeskieaspektydiversifikaciirossijsko-afganskihotnoŝenij” (Geopolitical aspects of the Afghan-Russian relationship), Institute of Orientalism, Russian Academy of Sciences, <www.ivran.ru> (February 20 2006).

Lillis, J. (2011, November 16). Kazakhstan: Astana Jolted by terror incidents. Retrieved from http://www.eurasianet.org

Mahapatra, A. D. (2009). Fatwa against terrorism. Retrieved from http://en.fondsk.ru/

Makerenko, T. (2001). Friendly co-operation brings mutual benefit. Jane's Intelligence Review, 13(2).

McGlinchey, E. (2005). Autocrats, Islamists, and the rise of radicalism in Central Asia. Current History, 104 (684), 336.

Menon, R. (2003). The new great game in Central Asia. Survival, 45 (2), 190.

Omelicheva, M. (2007). Ethnic dimension of religious extremism and terrorism in Central Asia. Paper presented at the annual meeting of the International Studies Association 48th Annual Convention, Hilton Chicago, CHICAGO, IL, USA. Retrieved from http://www. allacademic.com/

Omelicheva, M. Y. (2010). The ethnic dimension of religious extremism and terrorism in Central Asia. International Political Science Review, 31 (2), 170.

Public Opinion Trends (POT). (2001). Afghanistan series.

Ahmed Rashid. (2000). Taliban militant, oil, and fundamentalism in Central Asia. New Haven Connecticut: Yale University Press.

.(1999). The resurgence of Central Asia-Islam or nationalism. Karachi: Oxford University Press.

.(2002a). Central Asian elites, suddenly, shift into Revolt. Retrieved from euroasianet.org

.(2002b). Jihad: The rise of militant Islam in Central Asia. London: Yale University Press.

Radyuhin, V. (2006, Feb 2). Russia and the great game in Central Asia. Hindu. Retrieved from http://web6.infotrac.galegroup.com 
Roy, A., \& Johnson, L. (Eds.). (2001). Central Asian security: The new international context. Washington: Brookings Institution Press.

Roy, M. S. (2004). Terrorism in Central Asia: Imperatives for regional cooperation. In Mahavir Singh (Eds.), International terrorism and regional extremism: Challenges to Central and South Asia. New Delhi: Anamika Publisher.

"RossiâspisaladolgAfghanistanu" (Russia cancelled most of Afghanistan’s debt). ( 2008) Retrieved from http://ntv.ru

BBC News. (2005, July 30). US asked to leave Uzbek airbase. Retrieved from news.bbc. co.uk

RIA Novosti. (2002, February 8). Voenno-tehni_eskoesotrudni_estvo Rossi iso stranamidal 'negozarubež'â" (Militaryand technical cooperation of Russia with the countries of the Far Abroad).

Withington, T. (2002). The other allies: Russia, India and Afghanistan's United Front. Current History, 101(651), 36-48.

Wishnik, E. (2002). Growing U.S. security interests in Central Asia [Monograph]. Retrieved from strategicstudiesinstitute.army.mil

World Development Report. (2012). Retrieved from www.wdronline.worldbank.org

Huma Yusuf. (2009, February 5). Kyrgyzstan parliament delays vote on US base closing. Christian Science Monitor. Retrieved from www.csmonitor.com

Zbigniew, B. (1998). The grand chessboard: American primacy and its geostrategic imperatives. New York: Basic Books. 
